\title{
A fluorimetric and enzymatic method for the estimation of serum total bile acids
}

\author{
G. M. MURPHY, BARBARA H. BILLING, AND D. N. BARON \\ From the Departments of Medicine and Chemical Pathology, Royal Free Hospital, London
}

SYNOPSIS The enzymatic technique using $3 \alpha$-hydroxysteroid dehydrogenase for determining bile acids in blood has been modified by measuring the reduced nicotinamide adenine dinucleotide fluorimetrically. The increased sensitivity attained enables the concentration of total bile acids in serum to be estimated using $3 \mathrm{ml}$ for normal subjects and $1 \mathrm{ml}$ for jaundiced patients. The range of normal values in serum was found to be $0-4.7 \mu \mathrm{mol} / \mathrm{litre}$ for males and $1 \cdot 0-8 \cdot 2 \mu \mathrm{mol} /$ litre for females.

In the assessment of liver function most substances metabolized by the liver can be measured easily in plasma, except for bile acids, and a reasonably rapid and specific method for their investigation is therefore needed. All the methods previously available have disadvantages: gas liquid chromatography requires lengthy chemical treatment of the sample before analysis (Sandberg, Sjövall, Sjövall, and Turner, 1965) whilst fluorimetry (in concentrated sulphuric acid) depends for its specificity on an initial prolonged extraction and purification process (Panveliwalla, Lewis, Tabaqchali, and Wootton, 1970).

Marcus and Talalay (1956) described an NADlinked $3 \alpha$-hydroxysteroid dehydrogenase obtained from Pseudomonas testosteroni: this enzyme can be used for the quantitative assay of androsterone and of other androgens with a $3 \alpha$-hydroxyl substituent (Hurlock and Talalay, 1957). The bile acids (cholic acid, deoxycholic acid, chenodeoxycholic acid) are also $3 \alpha$-hydroxysteroids and will react with $3 \alpha$-hydroxysteroid dehydrogenase. The reaction may be represented as

Steroid alcohol + NAD $^{+} \rightleftharpoons$

$$
\text { Steroid ketone }+\mathrm{NADH}+\mathrm{H}^{+} \text {. }
$$

Completion of this reaction to the right can be ensured by the use of hydrazine as a ketone trapping agent. Iwata and Yamasaki (1964) used this reaction for the determination of bile acids in blood, and their technique was adapted by Turnberg and Anthony-Mote (1969) for the Roceived for publication 16 February 1970. determination of bile acids in bile. These authors measured NADH spectrophotometrically at $340 \mathrm{~nm}$ : Iwata and Yamasaki (1964) found the lowest practical limit of detection to be $5 \mu \mathrm{g}$ (approximately $0.01 \mu \mathrm{mol}$ ) in the final reaction mixture $(3 \mathrm{ml})$ which means that at least $20 \mathrm{ml}$ serum is needed if values for normal sera are to be estimated. By the use of fluorimetry for the determination of NADH (Lowry, Roberts, and Kapphahn, 1957) it is possible to measure $0.25 \mu \mathrm{g}$ (approximately $0.0005 \mu \mathrm{mol}$ ) of bile acid in the final reaction mixture $(2.05 \mathrm{ml})$.

Using the specific enzyme reaction, the initial purification need not be so exhaustive. In the method to be described the procedure of Frosch and Wagener (1967) is used: in this, after extraction of serum with hot ethanol, neutral lipids are almost completely removed by distribution in alkaline aqueous alcohol and ether-heptane. By combining the enzymatic conversion of bile acids with the fluorimetric determination of NADH it is possible to measure concentrations of bile acids as low as those found in normal serum.

\section{Method}

\section{APPARATUS}

The instrument used was a Locarte fluorimeter, model MK4, with a mercury lamp. An LF1 filter which transmits wavelengths from 254 to $400 \mathrm{~nm}$ 
was used on the primary (excitation) side, and an LF6 filter which transmits light of $470 \mathrm{~nm}$ and greater was used on the secondary (emission) side.

\section{REAGENTS}

Sodium pyrophosphate solution $(0 \cdot 1 \mathrm{M})$

The solution was adjusted to $p \mathrm{H} 10 \cdot 2$ with $0 \cdot 1 \mathrm{~N}$ $\mathrm{NaOH}$.

\section{Ethanolic sodium pyrophosphate solution}

This was prepared daily by adding $5 \mathrm{ml}$ absolute ethanol to $95 \mathrm{ml} 0 \cdot 1 \mathrm{M}$ sodium pyrophosphate solution.

\section{Ethanol}

A $50 \%$ solution was prepared by diluting absolute ethanol with water and the $p \mathrm{H}$ was adjusted to 9.5-10.5, using a glass electrode.

\section{Hydrazine hydrate $(0 \cdot 1 \mathrm{M})$}

This solution was prepared by adding $5 \mathrm{ml}$ hydrazine hydrate $(99-100 \%)$ to ice-cold water and then slowly adding $1.5 \mathrm{ml} 2 \mathrm{~N} \mathrm{H}_{2} \mathrm{SO}_{4}$. The volume was made up to $100 \mathrm{ml}$ with distilled water, the $p \mathrm{H}$ adjusted to $9 \cdot 5$, and the solution stored at $4^{\circ} \mathrm{C}$.

\section{$\beta$ Nicotinamide adenine dinucleotide (NAD)}

An approximately $2.4 \mathrm{mM}$ solution of $\beta$ nicotinamide adenine dinucleotide (obtained from Sigma Chemicals Co.) was prepared immediately before use by dissolving $35 \mathrm{mg}$ in $20 \mathrm{ml}$ aqueous $0.1 \mathrm{M}$ sodium pyrophosphate solution, $\mathrm{pH} \quad 10 \cdot 2$ (sufficient for 20 samples assayed in duplicate).

\section{$3 \times$-Hydroxysteroid dehydrogenase $(10 \mathrm{mg} / \mathrm{ml})$}

Hydroxysteroid dehydrogenase (obtained from Sigma Chemicals Co.) is a crude preparation of dried cells of Pseudomonas testosteroni containing $3 \alpha$-hydroxysteroid dehydrogenase, $3,17 \beta$ hydroxysteroid dehydrogenase, and other enzymes active in steroid metabolism. One hundred mg was ground, in a pestle and mortar, with a knife point of alumina in $1 \mathrm{ml}$ ice-cold water to ensure rupture of the bacterial cells. The volume was made up to $10 \mathrm{ml}$ with ice-cold water, and the resulting suspension mixed thoroughly and then centrifuged at $30,000 \mathrm{~g}$ for $40 \mathrm{~min}$ at $-0^{\circ} \mathrm{C}$. The clear supernatant was used for the bile acid assay. If analysis is carried out infrequently it is advisable to store the enzyme solution in small aliquots at $-20^{\circ} \mathrm{C}$. It may be kept for four days at $4^{\circ} \mathrm{C}$ without significant loss of activity.

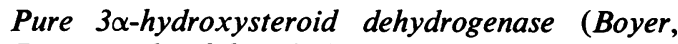
Baron, and Talalay, 1965)

This reagent was kindly provided by Dr Paul Talalay (Johns Hopkins University School of Medicine). A $10 \mathrm{mg} / \mathrm{ml}$ solution was prepared in the manner described for the Sigma hydroxysteroid dehydrogenase.

\section{Bile acid standard solution}

Bile acids were obtained from Maybridge Chemicals Ltd, Launcester, Cornwall, England. With the exception of cholic acid they were found to be $95 \%$ pure when examined by thin-layer chromatography. For conjugated bile acids the solvent system reported by Hofmann (1964) was employed, ie, water/ $\boldsymbol{n}$ propanol/propionic acid/isoamyl acetate $(1: 2: 3: 4, \mathrm{v} / \mathrm{v})$, and for unconjugated bile acids the system reported by Gregg (1966), ie, isooctane/isopropyl ether/glacial acetic acid/isopropyl alcohol $(2: 1: 1: 1, \mathrm{v} / \mathrm{v})$. The cholic acid preparation contained other bile acids present to a concentration of $25 \%$. As the bile acid present in the highest concentration in normal sera is glycocholic acid, this was selected as standard. A stock solution of sodium glycocholate, $2,050 \mu \mathrm{mol} / \mathrm{litre}$, was prepared by dissolving $100 \mathrm{mg}$ of the salt in $100 \mathrm{ml} 50 \%$ aqueous ethanol. From this stock solution working standards, ranging from $10 \cdot 25$ to $205 \mu \mathrm{mol} /$ litre $(5-100 \mu \mathrm{g} / \mathrm{ml})$, were prepared by diluting the stock solution with $50 \%$ aqueous ethanol.

\section{PURIFICATION OF SOLVENTS}

All organic solvents (AR grade) used, with the exception of diethyl ether, were redistilled from glass.

\section{Procedure}

Ten ml blood was collected from fasting subjects and the sera were stored at $-15^{\circ} \mathrm{C}$ in glass vials.

\section{EXTRACTION}

Three $\mathrm{ml}$ serum was pipetted dropwise into $15 \mathrm{ml}$ boiling ethanol in a $50-\mathrm{ml}$ conical flask, fitted with a simple air condenser and magnetically stirred. Heating was continued for five minutes. The flask was then allowed to cool to room temperature and the contents were centrifuged for five minutes at $2,000 \mathrm{~g}$. The supernatant solution was decanted into a stoppered glass tube, and the precipitate was agitated with $10 \mathrm{ml}$ absolute ethanol and the boiling-stirring procedure repeated. After centrifugation the ethanolic solutions were combined, and evaporated to dryness in a rotary evaporator. The residue was washed into a $60-\mathrm{ml}$ stoppered tube with $2 \times 5 \mathrm{ml}$ volumes of $50 \%$ ethanol and then extracted with $20 \mathrm{ml}$ ether/heptane $(1: 1, \mathrm{v} / \mathrm{v})$ by mechanical shaking for 20 minutes (not less than 10 minutes, not more than $25 \mathrm{~min}$, depending on the type of extractor used). The tube was then centrifuged at $1,000 \mathrm{~g}$ for 10 minutes, after which the upper phase was removed using a pasteur pipette and water pump, and the lower phase evaporated to dryness. The residue was then dissolved in $1 \mathrm{ml}$ $50 \%$ ethanol. 


\section{ENZYMATIC ASSAY}

The following solutions were prepared immediately before use. Reagent $A$ was prepared by adding $10 \mathrm{ml}$ hydrazine hydrate solution to $10 \mathrm{ml}$ NAD and $1 \mathrm{ml}$ enzyme solution contained in a $100 \mathrm{ml}$ volumetric flask, and made up to the mark with ethanolic pyrophosphate. Reagent B was prepared by adding $10 \mathrm{ml}$ hydrazine hydrate solution to $10 \mathrm{ml}$ NAD and diluted to $100 \mathrm{ml}$ with ethanolic pyrophosphate solution.

Tubes were set up, in duplicate, as follows:

\section{NAD blank}

To $50 \mu 150 \%$ ethanol was added $2 \mathrm{ml}$ reagent $\mathrm{B}$. This solution was used to measure the fluorescence of all the reagents without the enzyme preparation.

\section{Reagent blank}

To $50 \mu 150 \%$ ethanol was added $2 \mathrm{ml}$ reagent A. The fluorescence in this tube was derived from all the reagents, including the enzyme preparation. The latter is a large contributor to the blank and it is therefore necessary to keep the amount of enzyme preparation used to a minimum.

\section{Standard test}

To $50 \mu$ l of each working standard was added $2 \mathrm{ml}$ reagent $\mathrm{A}$. This solution was used to measure fluorescence due to the standard bile acidenzyme-NAD reaction and the background reagent fluorescence.

\section{Serum test}

To $50 \mu \mathrm{l}$ serum extract was added $2 \mathrm{ml}$ reagent $\mathrm{A}$. This solution was used to measure the fluorescence due to the serum bile acid-enzyme-NAD reaction, and the fluorescence due to serum and reagents.

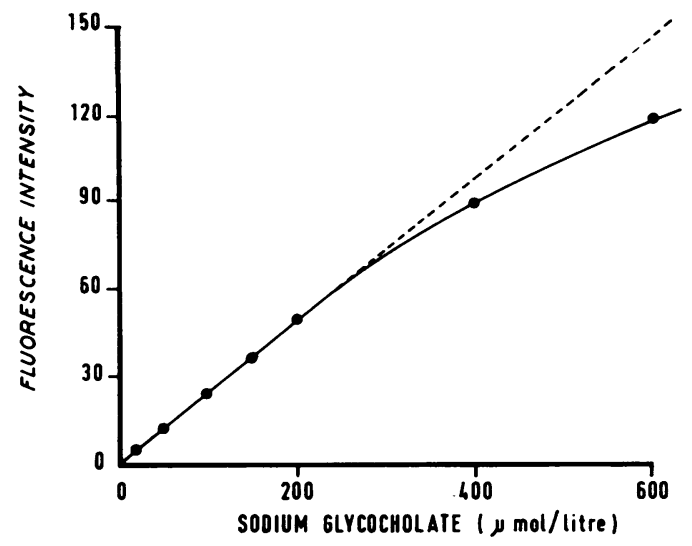

Fig. 1 Calibration curve for sodium glycocholate showing relationship between intensity of fluorescence (in galvanometer units) and concentration of standard solutions.
Serum blank

To $50 \mu \mathrm{l}$ serum extract was added $2 \mathrm{ml}$ reagento B. This solution was used to measure the back ground fluorescence due to serum and all the reagents except the enzyme preparation.

All the solutions were mixed thoroughly an the tubes placed in water at $37^{\circ} \mathrm{C}$ for 45 minute They were then placed at $-20^{\circ} \mathrm{C}$ for 10 minutes? The tubes were then taken from the refrigeratof and allowed to stand at room temperature fo 1 10 minutes so that the solutions were read wheg they had reached a temperature of 5 to $10^{\circ} \mathrm{C}$. It is essential that all readings are made at the same temperature, which should be as low as possiblet because of the high negative coefficient of fluorescence of NADH (Lowry et al, 1957; Gree and Israelstram, 1968).

\section{READING}

The galvanometer scale of the fluorimeter was se? at zero using the NAD blank, and the sensitivity controls were adjusted so that the top working standard read 50. The fluorescence of the solue tions was then read. The reading of the reagen blank was subtracted from the readings of the. standards and a calibration curve plotted in the usual way (Fig. 1). The curve was linear up to a bile acid standard concentration of $205 \mu \mathrm{mol} / \mathrm{litre}$ This is equivalent to a concentration of bile acis in the cuvette of $5 \mu \mathrm{mol} / \mathrm{litre}$.

\section{CALCULATION OF RESULTS}

The concentration of serum bile acids may be read from the standard graph and multiplied by the appropriate factor used in the extraction proe cedure (in the above description this is $1 / 3$ ), that is:

$$
\begin{aligned}
& \text { Concentration of total bile acids in serum ( } \mu \mathrm{mol} / \mathrm{litre} \\
& =\frac{\text { Serum test }- \text { (reagent blank }+ \text { serum blank) }}{\text { Standard }- \text { reagent blank) }}
\end{aligned}
$$

Concentration standard

$$
3
$$

\section{ARTIFICIAL FLUORESCENCE STANDARD}

If the fluorimeter is regularly in use for estiman tions other than bile acids it is convenient to seto the sensitivity of the fluorimeter with an artificial standard of fluorescence. The latter may be pres pared as described by Lewin, Wills, and Baroo (1969) from the epoxy resin Araldite, commerciales ly available in the Araldite adhesive pack, which contains both resin and hardener.

\section{Results and Discussion}

\section{TEMPERATURE OF INCUBATION}

Boyer, Baron, and Talalay (1965), using andro sterone as substrate, showed that the reaction 
rate of $3 \alpha$-hydroxysteroid dehydrogenase rises essentially linearly with temperature $\left(16-35^{\circ} \mathrm{C}\right)$. However, Turnberg and Anthony-Mote (1969) using sodium cholate as substrate found a fall-off in extinction at $340 \mathrm{~nm}$ at $37^{\circ} \mathrm{C}$. Using sodium glycocholate as substrate and hydrazine hydrate as a ketone trapping agent, the reaction was found to be complete at $37^{\circ} \mathrm{C}$ in $45 \mathrm{~min}$ (Fig. 2). Similar results were obtained with equimolar solutions of other bile acids (Fig. 3) and no reversal of the NAD/NADH reaction was observed with any of the bile acids tested (Table I).

\begin{tabular}{|c|c|c|}
\hline \multirow[t]{2}{*}{ Standard Solution } & \multicolumn{2}{|c|}{ Concentration ( $\mu$ mol/litre) } \\
\hline & Calculated & Estimated \\
\hline $\begin{array}{l}\text { Sodium taurocholate } \\
\text { Sodium taurodeoxycholate } \\
\text { Sodium taurochenodeoxycholate } \\
\text { Sodium glycochenodeoxycholate } \\
\text { Sodium glycodeoxycholate } \\
\text { Sodium taurolithocholate } \\
\text { Sodium glycolithocholate } \\
\text { Cholic acid } \\
\text { Deoxycholic acid } \\
\text { Chenodeoxycholic acid } \\
\text { Sodium lithocholate }\end{array}$ & $\begin{array}{l}151 \cdot 6 \\
179 \cdot 2 \\
112 \cdot 1 \\
219 \cdot 5 \\
222 \cdot 6 \\
164 \cdot 2 \\
155 \cdot 2 \\
222 \cdot 7 \\
187 \cdot 0 \\
209 \cdot 0 \\
160 \cdot 6\end{array}$ & $\begin{array}{l}149 \cdot 7 \\
179 \cdot 4 \\
112 \cdot 8 \\
215 \cdot 3 \\
221 \cdot 5 \\
166 \cdot 2 \\
153 \cdot 6 \\
235 \cdot 8 \\
185 \cdot 9 \\
208 \cdot 1 \\
155 \cdot 9\end{array}$ \\
\hline
\end{tabular}

Table I Comparison of analytical yield from aqueous solutions of different bile salts and bile acids

\begin{tabular}{|c|c|c|c|c|}
\hline $\begin{array}{l}\text { Total Bile Acid in } \\
\text { Serum ( } \mu \mathrm{mol} / \text { litre) }\end{array}$ & $\begin{array}{l}\text { Standard } \\
\text { Used }\end{array}$ & $\begin{array}{l}\text { Standard } \\
\text { Added ( } \mu g)\end{array}$ & $\begin{array}{l}\text { Standard } \\
\text { Recovered ( } \mu g)\end{array}$ & $\begin{array}{l}\text { Percentage } \\
\text { Recovery }\end{array}$ \\
\hline $\begin{array}{r}1 \cdot 4 \\
112 \cdot 8 \\
174 \cdot 0 \\
41 \cdot 2 \\
236 \cdot 0 \\
46 \cdot 0\end{array}$ & $\begin{array}{l}\text { Taurocholate } \\
\text { Taurocholate } \\
\text { Taurocholate } \\
\text { Glycocholate } \\
\text { Glycocholate } \\
\text { Lithocholate }\end{array}$ & $\begin{array}{r}104 \cdot 0 \\
104 \cdot 0 \\
104 \cdot 0 \\
73 \cdot 5 \\
73 \cdot 5 \\
60 \cdot 0\end{array}$ & $\begin{array}{l}87 \cdot 9 \\
91 \cdot 5 \\
88 \cdot 2 \\
61 \cdot 0 \\
63 \cdot 5 \\
51 \cdot 3\end{array}$ & $\begin{array}{l}85 \\
88 \\
85 \\
83 \\
86 \\
86\end{array}$ \\
\hline
\end{tabular}

Table II Recovery experiment

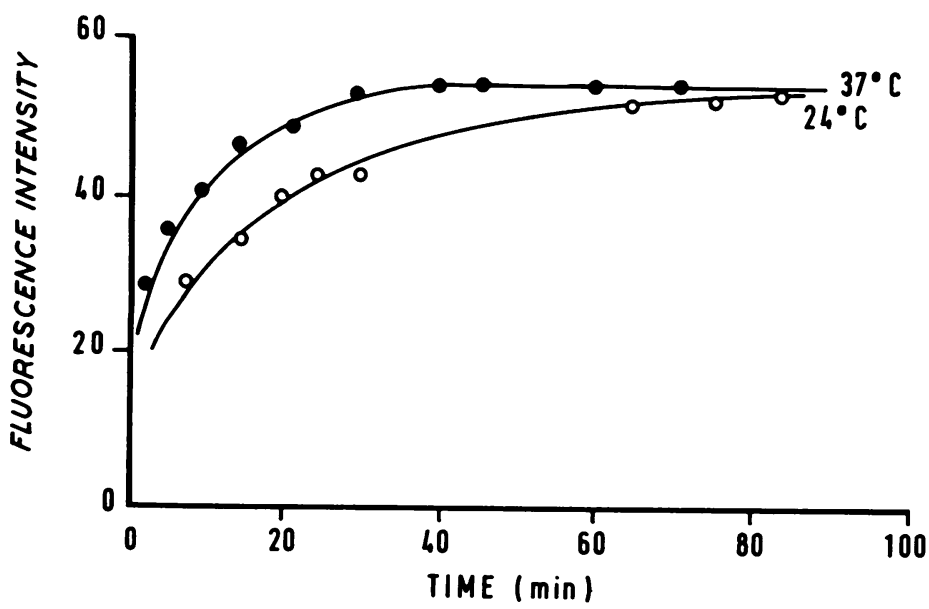

Fig. 2 Development of fluorescence with time at $24^{\circ} \mathrm{C}$ and $37^{\circ} \mathrm{C}$ using $50 \mathrm{\mu l}$ sodium glycocholate (200 $\mu \mathrm{mol} /$ litre) in the reaction mixture.
RECOVERY

Table II shows the results of recovery experiments performed by adding a standard aqueous solution to serum before the extraction procedure. The recovery, $83-88 \%$, was found to be independent of the original serum concentration and also of $\overline{\vec{w}}$ the bile acid used.

\section{PRECISION}

The precision of the method was determined as follows: (a) by considering the results of $\operatorname{six}^{\mathrm{C}}$. replicate determinations. The mean value was. $149.4 \mu \mathrm{mol} /$ litre, the standard deviation was $4 \cdot 4, \overrightarrow{\vec{\omega}}$ and the coefficient of variation was $3 \%$. (b) By ${ }_{\sigma}$ considering the results of duplicates of duplicate determinations, performed on 10 different sera, from different batches, and ranging in bile acid concentration from $2 \cdot 3$ to $256 \mu \mathrm{mol} / \mathrm{litre}$. The $v$ mean value of the results was $73.6 \mu \mathrm{mol} /$ litre, the standard deviation was $3 \cdot 1$, and the coefficient of variation was $4 \cdot 2 \%$.

PRACTICAL RANGE OF MEASUREMENT The smallest amount of NADH fluorimetrically detectable in a volume of $2 \mathrm{ml}$ was $0.0005 \mu \mathrm{mol} \overrightarrow{0}$ which gave a galvanometer deflection of approxi- $\bigcirc$ mately 2 units (galvanometer controls set at $\times 1$,

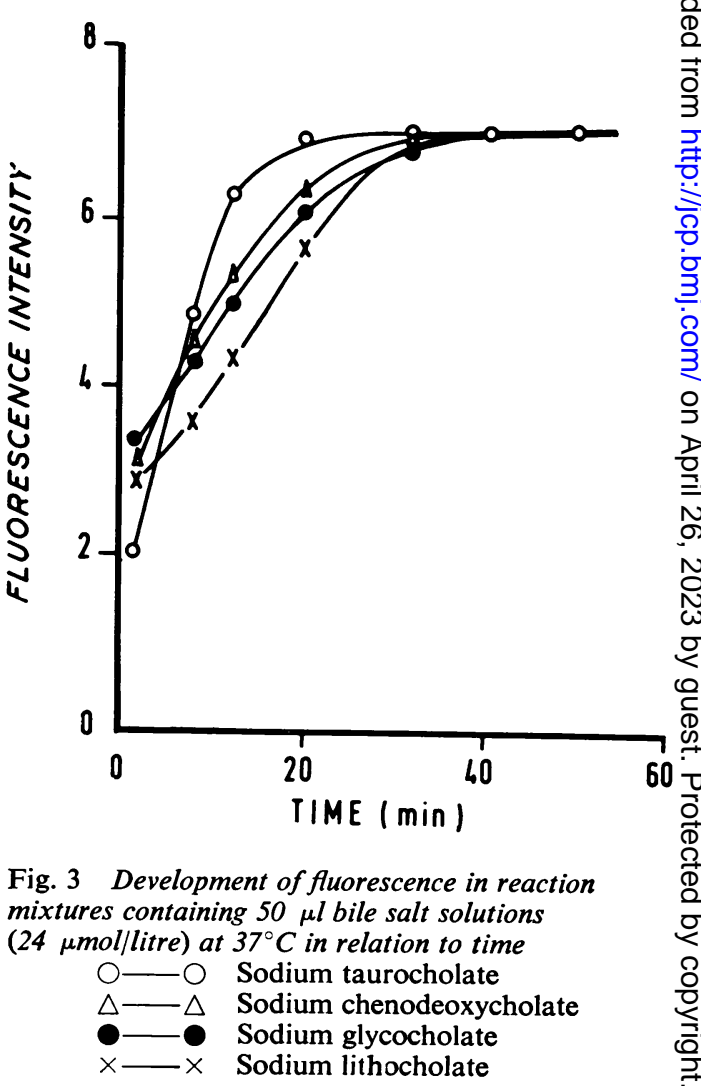


full scale deflection 14 units). This corresponds to a bile acid concentration in the alcoholic extract of $10 \mu \mathrm{mol} /$ litre. Hence for low serum concentrations it is necessary to concentrate the serum during the extraction procedure 1 in 3 or 1 in 6 . If the serum tests give higher readings than the top standard of $205 \mu \mathrm{mol} /$ litre then the extracts should be diluted with $50 \%$ ethanol so as to avoid the quenching effects shown in Figure 1. Alternatively, as in the case of sera from patients with obstructive jaundice, smaller volumes of serum may be used, thus minimizing interference from bilirubin.

\section{SPECIFICITY}

By using an enzyme procedure with suitable blanks such problems as the necessity of separating bile pigments and phospholipids from the bile

\begin{tabular}{|c|c|c|c|c|}
\hline Method & Material & $\begin{array}{l}\text { Bile Acids } \\
\text { ( } \text { mmol/litre })\end{array}$ & $\begin{array}{l}\text { Recovery } \\
(\%)\end{array}$ & Author \\
\hline $\begin{array}{l}\text { Gas liquid } \\
\text { chromatography }\end{array}$ & Serum & $0.6-4.6$ (range) & $59-87$ & $\begin{array}{l}\text { Sandberg et al } \\
\text { (1965) }\end{array}$ \\
\hline $\begin{array}{l}\text { Gas liquid } \\
\text { chromatography }\end{array}$ & Serum & $0 \cdot 24-2 \cdot 9$ (range) & & $\begin{array}{l}\text { Makino, Naka- } \\
\text { gawa, and } \\
\text { Mashimo (1969) }\end{array}$ \\
\hline $\mathrm{H}_{2} \mathrm{SO}_{4} / \mathrm{UV}$ & Serum & $20-44$ (range) & & Carey (1956) \\
\hline $\begin{array}{l}\text { Thin-layer chroma- } \\
\text { tography }+ \\
\mathrm{H}_{2} \mathrm{SO}_{4} / \text { fluori- } \\
\text { metry }\end{array}$ & Serum & $<5$ (range) & $85-90$ & $\begin{array}{l}\text { Panveliwalla et al } \\
\text { (1970) }\end{array}$ \\
\hline $\begin{array}{l}\text { Enzyme spectro- } \\
\text { photometry }\end{array}$ & Blood & $\begin{array}{l}4 \cdot 4 \pm 1 \cdot 1(\text { mean } \\
\pm 1 \mathrm{SD})\end{array}$ & 82 & $\begin{array}{l}\text { Iwata and Yama- } \\
\text { saki (1964) }\end{array}$ \\
\hline Enzyme fluorimetry & Serum & $\begin{array}{l}\text { Male } 0-4 \cdot 7 \text { (range) } \\
\text { Female } 1 \cdot 0-8 \cdot 2 \text { (range) }\end{array}$ & $83-88$ & Present method \\
\hline
\end{tabular}

Table III Normal values for serum bile acids

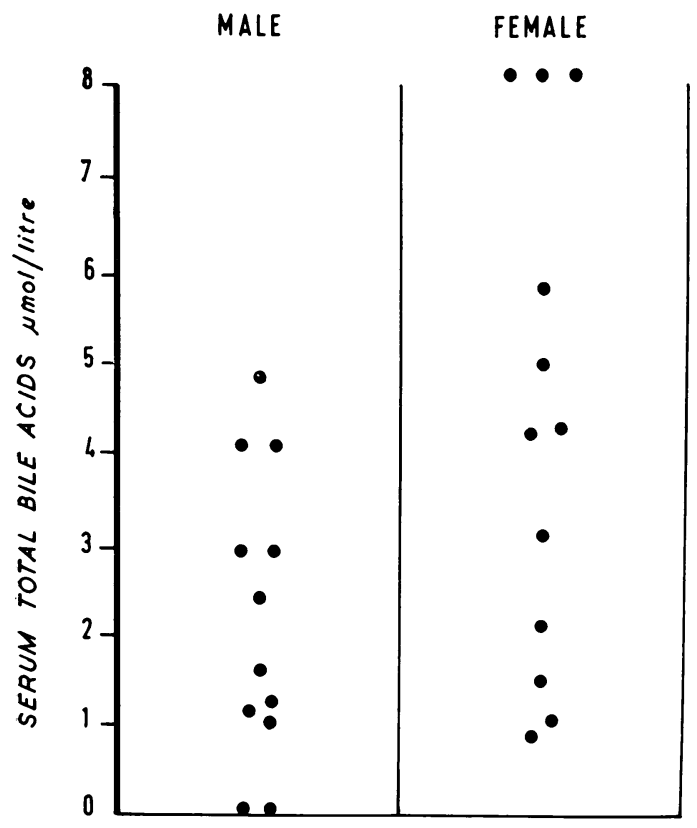

Fig. 4 Normal values for 12 females and 12 males. acids are minimized. However, the Sigma pre? paration is a mixture of $3 \alpha$-hydroxysteroif dehydrogenase and 3,17 $\beta$-hydroxysteroid dehy drogenases, so to check the specificity of the procedure, the results obtained using this preparation were compared with those obtained usin\% pure $3 \alpha$ hydroxysteroid dehydrogenase. No signio ficant difference between the two sets of resulto was observed thus demonstrating that in the above procedure only acidic steroids which werब $3 \alpha$ hydroxysteroids were measured.

\section{NORMAL VALUES}

Blood was collected from 24 fasting subjects (1 female and 12 male), mainly medical students ang radiography students. The serum total bile acids were estimated using the method described; the range for the male group was $0-4 \cdot 7 \mu \mathrm{mol} / \mathrm{litr}$ that for the female group 1.0-8.2 $\mu \mathrm{mol} /$ litre (Figs 4). The normal range of total bile acids in serurg found is similar to normal ranges taken from the. literature (Table III).

This work was supported by a grant from the Medical Research Council.

\section{References}

Boyer, J., Baron, D. N., and Talalay, P. (1965). Purification an $\bar{\AA}$ properties of a $3 \alpha$-hydroxysteroid dehydrogenase frop Pseudomonas testosteroni. Biochemistry, 4, 1825-1833.

Carey, J. B., Jr. (1956). The serum dihydroxy-trihydroxy bif acid ratio in liver and biliary tract disease. (Abstr.) 夸 clin. Invest., 35, 695-696.

Frosch, B., and Wagener, H. (1967). Quantitative determination of conjugated bile acids in serum in acute hepatitis. Nature (Lond.), 213, 404-405.

Green, W. G. E., and Israelstam, G. F. (1968). Increased sensitivity in fluorimetric determinations of nicotinamido nucleotide coenzymes. Canad. J. Biochem., 46, 390-392. ?

Gregg, J. A. (1966). New solvent systems for thin-layer chromato graphy of bile acids. J. Lipid Res., 7, 579-581.

Hofmann, A. F. (1964). Thin-layer chromatography of bile acios and their derivatives. In New Biochemical Separation? edited by A. T. James and L. J. Morris, pp. 261-282.

Hurlock, B., and Talalay, P. (1957). Principles of the enzymatif measurement of steroids. J. biol. Chem., 227, 37-52.

Iwata, T., and Yamasaki, K. (1964). Enzymatic determinations and thin-layer chromatography of bile acids in blood. Biochem. (Tokyo), 56, 424-431.

Lewin, M. R., Wills, M. R., and Baron, D. N. (1969). UltraA microfluorimetric determination of calcium in plasma. clin. Path., 22, 222-225.

Lowry, O. H., Roberts, N. R., and Kapphahn, J. I. (1957). Th尺 fluorimetric measurement of pyridine nucleotides. J. bio Chem., 224, 1047-1064.

Makino, I., Nakagawa, S., and Mashimo, K. (1969). Cor jugated and unconjugated serum bile acid levels in patiento with hepatobiliary diseases. Gastroenterology, 56, $103 \mathrm{~K}$

1)39.
Marcus, P. I. and Talalay P.(1956). Induction and Purification of $\alpha$ \& $\beta$ Hydroxysteroid Dehydrogenases. J. biol. Chem.त्र 218, 661-674.

Panveliwalla, D., Tabaqchali, S., Lewis, B., and Wootton? I. D. P. (1970). Determination of individual bile acids i biological fluids by thin-layer chromatography and fluor metry. J. clin. Path., 23, 369-314.

Sandberg, D. H., Sjövall, J., Sjövall, K., and Turner, D. A(1965). Measurement of human serum bile acids by gask liquid, chromatography. J. Lipid Res., 6 182-192.

Turnberg, L. A., and Anthony-Mote, A. (1969). The quantitative determination of bile salts in bile using thin-layer chromas tography and $3 x$ hydroxysteroid dehydrogenase. Clin chim. Acta, 24, 253-259. 